\title{
Container Multimodal Transport Channel In Shandong District Path Evaluation and Optimization
}

\author{
Xin $\mathrm{LI}^{1, \mathrm{a},{ }^{*}, \text { Feng-Yue MAO }}{ }^{1, \mathrm{~b}}$, Ji-Chun ZHANG ${ }^{1, \mathrm{c}}$ \\ ${ }^{1}$ Shandong Jiaotong University, Ji'nan 250357, China \\ ad894931905@qq.com, b1300607864@qq.com, ' 2924545582@qq.com \\ ${ }^{*}$ Corresponding author
}

Keywords: Container multimodal transport, Channel, Analytic Hierarchy Process(AHP).

\begin{abstract}
In order to optimize the container multimodal transport in Shandong district, researching for the development of container multimodal transport channel in Shandong district is starting from the model method of reasonable selection of transport path, it used hierarchy analysis method to evaluate the container multimodal transport channel in Shandong district, it studied to determine the optimal path of container multimodal transportation, it is establishing path evaluation and system of container multimodal transport channel in Shandong district.
\end{abstract}

\section{Introduction}

Container multimodal transport channel is gradually formed on the premise of the development of container intermodal transportation, container multimodal transport channel is in a certain geographical area where a variety of modes of transportation is available. How to choose the suitable way to determine the optimal path of container intermodal transportation and set up the path evaluation and system in Shandong district of container multimodal transport channel become the key of the research.

\section{To Establish Evaluation Index System of Container Multimodal Transport Channel Path}

It evaluates the channel conditions in the perspective of macroscopic. Setting up the index system is considering both social satisfaction and the owner satisfaction. The index are goods freight level, the duration of cargo transportation, the flexibility of the cargo transport, the security of the cargo transport, the owner preference, the rational use of resources, environmental protection degree of the path, opportunities to increase employment, the influence of impact on the comprehensive transportation system. Through the investigation and study, a large number of facts in the nine indicators of the index system, the first five indicators is most concerned problems in the process of container transport for the owner of the goods, it is the direct impact on the owner to choose path. The remaining four indicators from the state's overall interests as a starting point, to constraints of path selection, which can achieve the best environmental protection container transport, the most effective resource utilization, it needs relevant policies to achieve two indicators of container cargo for owners to choose path constraint.

\section{The Model and Steps of Channel Routing Method}

The AHP is used to calculate each index weight.AHP to calculate the index weight method is as follows: Structure judgment matrix. This is the key step in the AHP.

It uses three scale judgment instead of the original judgment which is difficult to give exactly nine scale to construct comparison matrix C. 


$$
C_{i j}\left\{\begin{array}{l}
0=i \text { more important than } j \\
1=i, j \text { are equally important } \\
2=j \text { more important than } i
\end{array}\right.
$$

Calculate the importance ranking index of each element:

$$
r i=\sum_{i=1}^{n} \operatorname{cij},(i=1,2,3, \ldots n), \text { take }^{r \max }=\max \{r i\}, \quad r \min =\min \{r i\}
$$

Calculate the elements of the judgement matrix

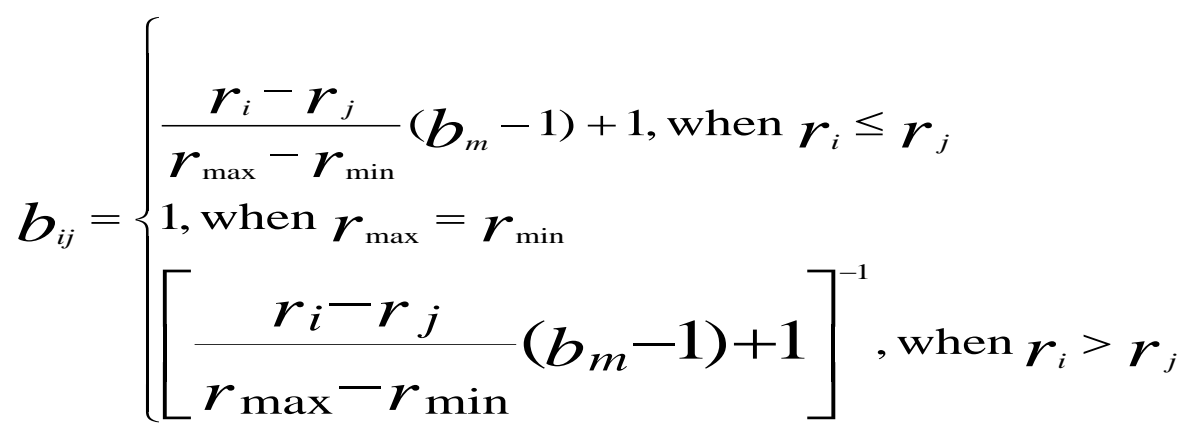

take $b_{m}=r_{\text {max }} / r_{\text {min }}$

Calculating the characteristic vector of judgment matrix

It uses the root mean square method to calculated the approximate results:

$$
\overline{w i}=\sqrt[n]{\sum_{j=1}^{n} b i j}, i=1,2, \ldots \ldots, n
$$

Take $\overline{w i}$ normalization:

$$
\bar{w}=\frac{\overline{w i}}{\sum_{i=1}^{n} \overline{w i}}, i=1,2, \ldots . ., n
$$

Obtain $^{\bar{w}}=(w 1, w 2, \ldots \ldots, w n)^{T}$, that is the approximate value of the eigenvector, which is the relative weight of each factor.

Calculate the maximum eigenvalue of a matrix $\lambda_{\max }:$

$$
\lambda_{\max }=\sum_{i=1}^{n} \frac{(\overline{\Delta w})_{i}}{n \overline{w_{i}}}
$$

$(A \bar{w})_{i}$ is the first ${ }^{i}$ elements for vector $A w$.Consistency test of judgment matrix

$$
C . I=\frac{\lambda_{\max }-n}{n-1}
$$

The consistency of judgement matrix of $n$, the greater the judgment is the worse, so bring in modification value $R . I$, and taking 


$$
\operatorname{C.R}=\frac{\operatorname{C.I}}{\boldsymbol{R} \cdot \boldsymbol{I}}
$$

\section{Container Multimodal Transport Channel Path Evaluation in Shandong District}

Shandong regional economic development is rapid, in the process of container transportation, international container transportation proportion is larger, and the exit channel is varied, this article selects several channel as evaluation objects, including Yangtze sea route, the pearl river delta sea route, the northern gulf sea route, and the new Eurasian continental bridge. Due to Rotterdam is another terminal of the new Eurasian continental bridge, it is considering the direction of channel and the principle of load and water balance, it selects the Rotterdam port of final points for each path.

\section{Multimodal Transport Route Choice Analysis of Shandong and Surrounding Areas to Rotterdam Which in Europe}

Path one: Shandong around---Shandong---Shanghai Rotterdam Path two: Shandong around---Shandong===Shanghai Rotterdam Path three: Shandong around---Shandong $\approx \approx \approx$ Shanghai $\sim \sim$ Rotterdam Path four: Shandong around---Shandong---Shenzhen Rotterdam Path five: Shandong around----Shandong $===$ Shenzhen Rotterdam Path six: Shandong around---Shandong ---The bohai sea Rotterdam Path seven: Shandong around---Shandong=== The bohai sea Rotterdam Path eight: Shandong around ---Shandong $===$ Alataw Pass $\sim \sim \sim$ Rotterdam

Among them: $\sim \sim$ for overseas shipping, $\approx \approx \approx$ for inland water transport,$===$ for railway transportation, --- for road transport.

\section{The Path Condition Basic Data}

It considering 1 TEU container the path optimization from Shandong to Rotterdam, each road are including inland transportation stage (including port and dock stagnation, loading and unloading cost and time) and the phase of maritime transport.

Take the yuan against the dollar to 6.8, total freight and total time of the path as shown in table 1 .

Table1 Route total transport costs, time

\begin{tabular}{|c|c|c|}
\hline & Cost (RMB) & Total shipping time(days) \\
\hline Path one & 17366 & 29.5 \\
\hline Path two & 16627 & 30.2 \\
\hline Path three & 15780 & 32 \\
\hline Path four & 16871 & 27.3 \\
\hline Path five & 16010 & 27.9 \\
\hline Path six & 15476 & 30.4 \\
\hline Path seven & 15143 & 30.6 \\
\hline Path eight & 34826 & 19.5 \\
\hline
\end{tabular}

\section{Calculation Process and Results}

\section{Quantifies the Qualitative Indexes}

Based on the data rate method, combined with the specific situation in shandong, please industry experts scoring for the convenience of each path, security, resource reasonable degree, and environmental protection, the scores as shown in table 2. 
Table 2 Evaluation of qualitative indicators

\begin{tabular}{|l|c|c|c|c|c|c|c|}
\hline & Flexibility & Security & $\begin{array}{l}\text { The owner } \\
\text { preference }\end{array}$ & $\begin{array}{l}\text { The rational } \\
\text { use of } \\
\text { resources }\end{array}$ & $\begin{array}{l}\text { Environmental } \\
\text { protection } \\
\text { degree }\end{array}$ & $\begin{array}{l}\text { Employment } \\
\text { opportunities }\end{array}$ & $\begin{array}{l}\text { The } \\
\text { impact on } \\
\text { the traffic }\end{array}$ \\
\hline $\begin{array}{l}\text { Path } \\
\text { one }\end{array}$ & 9 & 6 & 8 & 7 & 8 & 8 & 6 \\
\hline $\begin{array}{l}\text { Path } \\
\text { two }\end{array}$ & 7 & 9 & 7 & 8 & 7 & 9 & 7 \\
\hline $\begin{array}{l}\text { Path } \\
\text { three }\end{array}$ & 8 & 8 & 9 & 9 & 9 & 7 & 8 \\
\hline $\begin{array}{l}\text { Path } \\
\text { four }\end{array}$ & 8 & 6 & 6 & 7 & 7 & 6 & 7 \\
\hline $\begin{array}{l}\text { Path } \\
\text { five }\end{array}$ & 7 & 7 & 5 & 7 & 7 & 6 & 6 \\
\hline $\begin{array}{l}\text { Path } \\
\text { six }\end{array}$ & 8 & 7 & 6 & 9 & 7 & 5 & 7 \\
\hline $\begin{array}{l}\text { Path } \\
\text { seven }\end{array}$ & 7 & 9 & 8 & 8 & 8 & 6 & 8 \\
\hline $\begin{array}{l}\text { Path } \\
\text { eight }\end{array}$ & 9 & 9 & 7 & 9 & 6 & 5 & 7 \\
\hline
\end{tabular}

Calculate Each Index Weight

AHP is used to calculate transportation cost, shipping time, convenience, security, and owner's preference for the weight of the owner's satisfaction, for consistency check. According to the formula (1) the following comparison matrix table 3.

Table 3 Comparison matrix owner satisfaction qualitative index weight

\begin{tabular}{|l|c|c|c|c|c|}
\hline & $\begin{array}{c}\text { Transportation } \\
\text { costs }\end{array}$ & $\begin{array}{c}\text { Transportation } \\
\text { time }\end{array}$ & Flexibility & Security & $\begin{array}{c}\text { The owner } \\
\text { preference }\end{array}$ \\
\hline $\begin{array}{l}\text { Transportation } \\
\text { costs }\end{array}$ & 1 & 2 & 2 & 2 & 2 \\
\hline Transportation time & 0 & 1 & 2 & 2 & 2 \\
\hline Flexibility & 0 & 0 & 1 & 1 & 2 \\
\hline Security & 0 & 0 & 1 & 1 & 2 \\
\hline $\begin{array}{l}\text { The owner } \\
\text { preference }\end{array}$ & 0 & 0 & 0 & 0 & 1 \\
\hline
\end{tabular}

Using the formula (2) (3), the judgment matrix table 4 below.

Table 4 The owner satisfaction qualitative index weight judgment matrix

\begin{tabular}{|l|c|c|c|c|c|}
\hline & $\begin{array}{c}\text { Transportation } \\
\text { costs }\end{array}$ & $\begin{array}{c}\text { Transportation } \\
\text { time }\end{array}$ & Flexibility & Security & $\begin{array}{c}\text { The owner } \\
\text { preference }\end{array}$ \\
\hline $\begin{array}{l}\text { Transportation } \\
\text { costs }\end{array}$ & 1 & 3 & 6 & 6 & 9 \\
\hline $\begin{array}{l}\text { Transportation } \\
\text { time }\end{array}$ & $1 / 3$ & 1 & 4 & 4 & 7 \\
\hline Flexibility & $1 / 6$ & $1 / 4$ & 1 & 1 & 4 \\
\hline Security & $1 / 6$ & $1 / 4$ & 1 & 1 & 4 \\
\hline $\begin{array}{l}\text { he owner } \\
\text { preference }\end{array}$ & $1 / 9$ & $1 / 9$ & $1 / 4$ & $1 / 4$ & 1 \\
\hline
\end{tabular}


According to the formula (4) (5), we can calculate(0.248, $0.228,0.248,0.228,0.146$ ) is the feature vector approximation, this also is transportation cost, transportation time, convenience and safety for the relative weight of customer satisfaction.

Remember to A1 $=(0.248,0.28,0.248,0.28,0.1460)$, according to the formula(6), $\lambda_{\max }=5.059$

According to the formula (7) (8) and table 4.1 to $C R=0.013<0.1$, satisfy the consistency check.

In the same way, to calculate the impact of rational use of resources, environmental protection, employment opportunities, integrated transport system on social satisfaction. Using the comparison matrix, judgment matrix is calculated $(0.30,0.30,0.23,0.30)$ for feature vector approximation, this also is the degree of reasonable utilization of resources, environmental protection, employment opportunities, the influence of the comprehensive transportation system to the weight of social satisfaction. Remember to A2 $=(0.30,0.30,0.23,0.30)$

$$
\lambda_{\text {max }}=4.026 \mathrm{CR}=0.009<0.009 \text {, satisfy consistency check. }
$$

Assuming that the owner's satisfaction and social satisfaction are weights of the total target (0.7, $0.3)$, record as $A=(0.7,0.7)$

The fuzzy synthesis is carried out by using the formula (2.3). The calculation results are as follows:

$$
\begin{aligned}
& B 1=A 1 \times R 1=\left|\begin{array}{llllllll}
0.590 & 0.540 & 0.559 & 0.517 & 0.508 & 0.545 & 0.579 & 0.525
\end{array}\right| \\
& B 2=A 2 \times R 2=\left|\begin{array}{llllllll}
0.537 & 0.538 & 0.554 & 0.470 & 0.457 & 0.504 & 0.510 & 0.457
\end{array}\right| \\
& B=A \times R=\mid \begin{array}{llllllll}
0.574 & 0.540 & 0.557 & 0.503 & 0.493 & 0.533 & 0.558 & 0.504
\end{array}
\end{aligned}
$$

As can be seen from the results, the comprehensive evaluation of the eight paths are arranged as follows: the path one, path seven, path three, path two, path six, path eight, path four, path five. The

\begin{tabular}{|c|c|c|c|}
\hline $\begin{array}{l}\text { Evaluation } \\
\text { rank }\end{array}$ & Path & Path to the prominent advantages & $\begin{array}{l}\text { Path to the main } \\
\text { disadvantages }\end{array}$ \\
\hline 1 & $\begin{array}{l}\text { Path } \\
\text { one }\end{array}$ & Time is short, and high sensitivity & $\begin{array}{l}\text { Cost is a bit high, poor } \\
\text { safety }\end{array}$ \\
\hline 2 & $\begin{array}{l}\text { Path } \\
\text { two }\end{array}$ & $\begin{array}{c}\text { Time is short, safety coefficient is big, } \\
\text { cost is low }\end{array}$ & $\begin{array}{l}\text { Poor flexibility, low degree } \\
\text { of environmental protection }\end{array}$ \\
\hline 3 & $\begin{array}{l}\text { Path } \\
\text { three }\end{array}$ & $\begin{array}{c}\text { Low cost, large capacity, high degree } \\
\text { of environmental protection, reasonable } \\
\text { utilization of resources }\end{array}$ & $\begin{array}{l}\text { Flexibility is poor, provide } \\
\text { employment will be less }\end{array}$ \\
\hline 4 & $\begin{array}{l}\text { Path } \\
\text { four }\end{array}$ & $\begin{array}{l}\text { High safety coefficient, provide more } \\
\text { employment opportunities }\end{array}$ & $\begin{array}{l}\text { Poor flexibility, low degree } \\
\text { of environmental protection }\end{array}$ \\
\hline 5 & $\begin{array}{l}\text { Path } \\
\text { five }\end{array}$ & Relatively short time & $\begin{array}{l}\text { Provide employment will be } \\
\text { less, low safety factor }\end{array}$ \\
\hline 6 & $\begin{array}{l}\text { Path } \\
\text { six }\end{array}$ & The shortest time and high safety & $\begin{array}{l}\text { High cost, provide } \\
\text { employment will be less }\end{array}$ \\
\hline 7 & $\begin{array}{c}\text { Path } \\
\text { seven }\end{array}$ & The flexibility is relatively good & Poor safety \\
\hline 8 & $\begin{array}{l}\text { Path } \\
\text { eight }\end{array}$ & The cost is relatively low, high safety & $\begin{array}{c}\text { The low degree of } \\
\text { environmental protection }\end{array}$ \\
\hline
\end{tabular}
optimal path is path one. From the territory of the various directions of the path to sum up the evaluation, each rank path and advantages as shown in table 5.

Table 5 Analysis of the advantages of each path 


\section{Summary}

Using AHP to get the optimal path for a, can be seen from the path advantage analysis, the path is a major advantage of time is short, high sensitivity, main disadvantage, slightly high cost, poor safety. Disadvantages relative to other path, a relatively optimal, can satisfy the two aspects of social satisfaction and the owner satisfaction of requirements, so the optimal path.

\section{References}

[1] Jigang Wei. Chaohe Rong.The Analysis of Macroeconomic Factors in the Development of China 's Container Multimodal Transport[J]. Chinese soft science.2000 (8).40-44

[2] Yonglv Qian. International container multimodal transport [J]2007 (9).1-3

[3] Huijiong Wang. The international experience and Enlightenment of the development of contain er multimodal transport [J].2005 (12).1l-14

[4] Jun Hai. Development of container multimodal transport in China [J]. port economy.2007 (7).4 5-45 